senior house officers could be given personal education plans, with regular monitoring of their progress and the prospect of effective responses to difficulties.

The report calls on the colleges and faculties to consider training senior registrars and consultants so that they can better undertake teaching, which should be required of them. The controlled system of appointing general practice trainers is praised, and the need for similar formal and skilled teaching of hospital juniors is emphasised. The report wants senior house officers to be given half day release study sessions to allow them to attend formal teaching in the same way as general practice trainees. Senior house officers should have named people to supervise them and advise them when they run into difficulties. Too often the education of the senior house officer is pushed aside by other concerns. Private study leave is often denied and attendance at courses severely restricted because of financial and staffing pressures. As a result morale is very low among many senior house officers. The health service can only benefit from having a more closely monitored, better informed team of senior house officers.

Allowing senior house officers reasonable study leave and ensuring that rotas are not so onerous as to make study impossible will cost money. The report recommends that staffing in certain specialties should be increased to ease the difficulties of providing cover. This carries the risk that the career pyramid will become even steeper, and the suggestion that intermediate grade and part time senior house officers could provide the extra cover might lead to a two class system with excellent education for some and little for the rest. This must be carefully planned if inequalities are to be avoided. With beds closing and operating lists being cut across Britain it is unrealistic to expect the needs of senior house officers to receive much support, but doctors must emphasise that medical education is not a luxury: it is essential for improving patient care. The report contains a progia.ime fn implementing its recommendations, many of which coula vi quickly and inexpensively introduced. Many senior house officers think that their education is already being sacrificed as an acceptable and almost invisible means of cutting costs. As the report says, "The belief that postgraduate medical education can be provided by enthusiastic amateurs in nonexistent time is no longer tenable."

STELla LOWRY

Assistant Editor, $B M \mathcal{F}$

1 Council for Postgraduate Medical Education in England and Wales. The problems of the senior house officer. London: 1987.

\section{Psychosocial factors and hypertension}

There is much interest in how psychosocial factors such as occupational stress, personality trait, and socioeconomic state may be related to hypertension, but the relation is highly complex and difficult to unravel. ${ }^{1}$ Social groups differ in their diets and alcohol intake, in their genetic characteristics, and in their prevalence of obesity, all of which may confound any relation between psychosocial factors and the prevalence of hypertension. Furthermore, whether a person seeks and complies with medical care is affected by psychosocial background, ${ }^{2-4}$ and a diagnosis of hypertension may alter psychological health..$^{5-7}$
Many investigations of this complex relation show flaws in methods: measurements of blood pressure may not be blind, measurement techniques may vary from group to group, and inferences about causation may be drawn unjustifiably from cross sectional studies. Psychological characteristics and psychiatric symptoms are difficult to measure reproducibly, and spells of hypertension recorded in the laboratory may not indicate sustained disease. Patients with hypertension may react to stress differently from those with normal blood pressure ${ }^{8}$ and those who are treated or observed may differ psychologically from others. ${ }^{9}$

Occupational stress arises when a person experiences excessive psychological or physical workload with little control over how the work is to be conducted. ${ }^{10}$ Studies relating occupational stress to hypertension are made difficult by the "healthy worker effect" and by confounding factors such as race, age, social class, and area of residence. A recent study that found an increased prevalence of hypertension in male bus drivers largely succeeded in controlling for these variables, but the authors emphasise that driving a bus differs from other occupations in many ways including the degree of physical activity, disruption of diet and sleep, and exposure to atmospheric pollutants and noise. "This increased rate of hypertension was not explained by race or age, but the effect of body mass index has not apparently been excluded.

Noise is a comparatively easily studied element of the occupational environment, yet a recent series of Dutch papers concludes that no relation has been established between total exposure to noise and blood pressure. ${ }^{12}$ There may, however, be a subset of patients at increased risk for both hearing loss and hypertension. ${ }^{13}$ Hearing loss itself could add to stress, or, if both hearing loss and raised blood pressure are caused by arteriosclerosis, other undiagnosed effects of this condition could add to the stress of performing sompetently at work.

Studying the relation of personality traits and socioeconomic status is even more difficult than studying the relation to occupational stress. Behavioural traits may not be invariant but may indicate responses to specific economic, social, or interpersonal problems. ${ }^{1}$ Although difficulties with submissiveness and anger expression, prolonged attempts to cope with stress ${ }^{14-16}$ and an unsupportive social structure, ${ }^{17} 18$ and tension within the family ${ }^{19}$ have often been related to an increased prevalence of hypertension, the results remain inconclusive and difficult to interpret. ${ }^{20}$ When there are so many variables and when each may contribute little to the total effect, showing the importance of individual factors may be beyond the competence of epidemiology. ${ }^{21}$ None the less, probable associations have been considered adequate bases for preventive action in other subjects, and perhaps the same should apply for adverse psychosocial factors that are remediable.

The contents of this article represent the author's views alone and do not commit the Department of Health and Social Security.

GILLIAN GREENBERG

Senior Medical Officer,

Department of Health and Social Security,

London SE1 6BY

1 Krantz DS, DeQuattro V, Blackburn HW, et al. Task force I: Psychosocial factors in hypertension. Circulation 1987;76(suppl I):84-8.

2 Williams CA, Beresford SAA, James SA, et al. The Edgecombe County high blood pressure control program: III. Social support, social stressors, and treatment dropout. Am F Public Health 1985;75:483-6.

3 Marmot MG. Psychosocial factors and blood pressure. Prev Med 1985;14:451-65. 
4 Nissinen A, Tuomilehto J, Salonen JT, Kottke TE, Piha T. The influence of socioeconomic factors on blood pressure control during a community-based hypertension control programme. Acta Cardiol 1986;41:99-109.

5 Mann $\mathrm{AH}$. The psychological effect of a screening programme and clinical trial for hypertension upon the participants. Psychol Med 1977;7:431-8.

6 Macdonald LA, Sackett DL, Haynes RB, Taylor DW. Labelling in hypertension: review of the behavioural and psychological consequences. $f$ Chronic Dis 1984;37: 933-42.

7 Anonymous. More on hypertensive labelling [Editorial]. Lancet 1985;i:1138-9.

8 Steptoe A. Stress mechanisms in hypertension. Postgrad Med f 1986;62:697-9.

9 Jern S. Psychological and hemodynamic factors in borderline hypertension. Acta Med Scand (Suppl) 1982;660:7-54.

10 Karasek R, Baker D, Marxer F, Ahlbom A, Theorell T. Job decision latitude, job demands, and cardiovascular disease: A prospective study of Swedish men. Am f Public Health 1981;71:694-705.

11 Ragland DR, Winkelby MA, Schwalbe J, et al. Prevalence of hypertension in bus drivers. Int $\mathcal{F}$ Epidemiol 1987;16:208-14

12 van Dijk FJH, Ettema JH, Zielhuis RL. Non-auditory effects of noise in industry. VII Evaluation, conclusions and recommendations. Int Arch Occup Environ Health 1987;59: 147-52.

13 Talbott E, Helmkamp J, Matthews K, Kuller L, Cottington E, and Redmond G Occupational noise exposure, noise-induced hearing loss, and the epidemiology of high blood pressure. Am f Epidemiol 1985;121:501-14.

14 Cottington EM, Brock BM, House JS, Hawthorne VM. Psychosocial factors and blood pressure in the Michigan statewide blood pressure survey. Am $\mathcal{F}$ Epidemiol 1985;121: 515-29.

15 Julius M, Harburg E, Cottington EM, Johnson EH. Anger-coping types, blood pressure, and all-cause mortality: a follow-up in Tecumseh, Michigan (1971-1983) Am 7 Epidemiol 1986;124:220-33.

16 James SA. Psychosocial precursors of hypertension: a review of the epidemiologica evidence. Circulation 1987;76(suppl I):60.

17 Strogatz DS, James SA. Social support and hypertension among blacks and whites in a rural, southern community. Am $\mathcal{F}$ Epidemiol 1986;124:949-56.

18 Liebman M, Chopin LF, Carter E, Clark AJ, Disney GW, Hegsted M, et al. Factors related to blood pressure in a biracial adolescent female population. Hypertension related to blood $1986 ; 8: 843-50$.

19 Lindgärde F, Furu M, Ljung B-O. A longitudinal study on the significance of environmental and individual factors associated with the development of essential hypertension. 7 Epidemiol Community Health 1987;41:220-6.

20 Moll PP, Harburg E, Burns TL. Schork MA, Ozgoren F. Heredity, stress and blood pressure, a family set approach: the Detroit project revisited. $\mathcal{F}$ Chronic Dis 1983;36: 317-28.

21 Aro S. Occupational stress, health-related behaviour, and blood pressure: a 5-year follow-up. Prev Med 1984;13:333-48.

\section{Services for sickle cell disease: unified approach needed}

Sickle cell disease is an autosomal recessive disorder affecting one in 30 blacks of Afro-Caribbean origin. ' The prevalence of the carrier state is no less than twice that of cystic fibrosis in the white population..$^{23}$ About the same number of people in the UK suffer from sickle cell disease as from haemophilia A (5000 (C Brown, Policy Studies Institute, London, unpublished observations)) and both the disease and asymptomatic carrier state can be easily detected by a blood test. Some $10-20 \%$ of people die from the disease in the first 10 years of life, ${ }^{45}$ and sufferers have a haemolytic anaemia and recurrent painful vaso-occlusive crises for all their lives. ${ }^{6}$ In later life renal failure and bone necrosis cause chronic disability. Time lost from school leads to poor educational achievement and high unemployment, ${ }^{7}$ and the economic and social cost to an already disadvantaged community is substantial.

The coordination of services for those with sickle cell disease-whether clinical, social, educational, or employment-requires a lead from the Department of Health and Social Security, supported by funding. The department, however, insists that this provision is a matter for district health authorities. ${ }^{8}$ The effect of this policy is apparent from a report, commissioned by the east London branch of the Sickle Cell Society, about services for sickle cell disease in the London Borough of Newham. ${ }^{9}$ This describes an almost total lack of facilities compounded by poor liaison among general practitioners, hospitals, and the community. Inadequate, or incorrect, and condescending advice seems to have been all that was available from health workers. Not surprisingly, the black community perceives this paucity of services as racist, although it would seem familiar to the haemophiliac of 20 to 30 years ago.

Happily, things are improving in Newham, with clinics becoming organised and access to hospital being improved. But it remains difficult to convince health service administrators in general of the scale of the problem and of the need for established funding of educational, screening, and counselling services. "Support," but no money, is usually all that is forthcoming. A satisfactory solution to the medicosocial problems of sickle cell disease could be achieved cheaply using the successful model of haemophilia care, and the scheme could operate under similar sponsorship by the Department of Health. Most of the requirements have already been indentified. ${ }^{2} 10$

In the districts the care of patients with sickle cell disease should be concentrated around a team, comprising the haematologist, paediatrician, and obstetrician, and together they would provide consistent management throughout the patient's life. General practitioners in areas of high incidence of the disease, identified as described in the Newham report, should receive specialised information and training.

Screening pregnant women from ethnic groups with a high incidence of haemoglobinopathies must be followed by testing the partners of carriers. Both antenatal diagnosis and selective abortion of affected pregnancies should then be offered to couples at risk. The Newham survey suggests that people are much more interested in antenatal diagnosis than has been thought.

Sickle cell counsellors have been of immense value in providing support and advice for patients and their families and education and screening for the community. They are also ideally placed to tackle educational and employment problems in both the school and the workplace. Probably one counsellor will be needed for every 50 sufferers and financial support is required urgently to establish these posts nationally.

Optimal management of sickle cell disease from the time of diagnosis at birth should help to reduce the morbidity and mortality in the early years of life, ${ }^{11}$ as well as improving the educational and employment prospects later. Eventually, greater awareness in the black community may lead to a reduction in the number of new cases of sickle cell disease.

In some parts of the UK these results will be achieved because of the efforts of individuals. Nevertheless, to ensure that patients everywhere can obtain specialist care, advice, and support will require a unified approach sponsored by the Department of Health. This will have the additional benefit of showing that professed commitments to ethnic minority health care really have some substance.

IAN M FRANKLIN

Consultant Haematologist,

Queen Elizabeth Hospital,

Birmingham B15 2TH

1 Brozovic M, Anionwu E. Sickle cell disease in Britain. J Clin Pathol 1984;37:1321-6.

2 Stuart J, Schwartz FCM, Little AJ, Raine DN. Screening for abnormal haemoglobins: a pilot study. BrMed $\mathcal{F}$ 1973;iv:284-7.

3 Crofton J, Douglas A. Respiratory diseases. Oxford: Blackwell Scientific Publications, 1981.

4 Mann JR. Sickle haemoglobinopathies in England. Arch Dis Child 1981;138:44-8.

5 Brozovic M, Davies S. Management of sickle cell disease. Postgrad Med J 1987;63:605-9.

6 Serjeant GR. Sickle cell disease. Oxford: Oxford University Press, 1985.

7 Franklin IM, Atkin K. Employment of persons with sickle-cell disease and sickle-cell trait. f Soc Occup Med 1986;36:76-9.

8 Vaughan G. Written answers to questions. House of Commons Official Report (Hansard) 1981 Nov 12;12:col 169.

9 Black J, Laws S. Living with sickle cell disease. London: Sickle Cell Society, East London branch, 1986.

10 Prashar U, Anionwu E, Brozovic M. Sickle cell disease-who cares? London: Runnymede Trust, 1985.

11 Anonymous. Penicillin prophylaxis for babies with sickle cell disease [Editorial]. Lancet 1986;ii: $1432-3$. 